\title{
Plasma proteomic changes during hypothermic and normothermic cardiopulmonary bypass in aortic surgeries
}

\author{
TEIJI ODA ${ }^{1}$, AKANE YAMAGUCHI ${ }^{1}$, MASAO YOKOYAMA ${ }^{1}$, KOJI SHIMIZU ${ }^{1}$, \\ KOSAKU TOYOTA ${ }^{2}$, TETSURO NIKAI ${ }^{2}$ and KEN-ICHI MATSUMOTO ${ }^{3}$
}

${ }^{1}$ Division of Thoracic and Cardiovascular Surgery, Department of Surgery and ${ }^{2}$ Department of Anesthesiology,
Shimane University Faculty of Medicine; ${ }^{3}$ Department of Biosignaling and Radioisotope Experiment,
Interdisciplinary Center for Science Research, Organization for Research, Shimane University, Shimane, Japan

Received March 31, 2014; Accepted July 8, 2014

DOI: 10.3892/ijmm.2014.1855

\begin{abstract}
Deep hypothermic circulatory arrest (DHCA) is a protective method against brain ischemia in aortic surgery. However, the possible effects of DHCA on the plasma proteins remain to be determined. In the present study, we used novel high-throughput technology to compare the plasma proteomes during DHCA $\left(22^{\circ} \mathrm{C}\right)$ with selective cerebral perfusion (SCP, $\mathrm{n}=7$ ) to those during normothermic cardiopulmonary bypass $(\mathrm{CPB}, \mathrm{n}=7)$. Three plasma samples per patient were obtained during CPB: T1, prior to cooling; T2, during hypothermia; T3, after rewarming for the DHCA group and three corresponding points for the normothermic group. A proteomic analysis was performed using isobaric tag for relative and absolute quantification (iTRAQ) labeling tandem mass spectrometry to assess quantitative protein changes. In total, the analysis identified 262 proteins. The bioinformatics analysis revealed a significant upregulation of complement activation at T2 in normothermic CPB, which was suppressed in DHCA. These findings were confirmed by the changes of the terminal complement complex (SC5b-9) levels. At T3, however, the level of SC5b-9 showed a greater increase in DHCA compared to normothermic $\mathrm{CPB}$, while 48 proteins were significantly downregulated in DHCA. The results demonstrated that DHCA and rewarming potentially exert a significant effect on the plasma proteome in patients undergoing aortic surgery.
\end{abstract}

\section{Introduction}

Hypothermia $<32-34^{\circ} \mathrm{C}$ has been clinically utilized only in cardiovascular surgery with cardiopulmonary bypass (CPB)

Correspondence to: Professor Teiji Oda, Division of Thoracic and Cardiovascular Surgery, Department of Surgery, Shimane University Faculty of Medicine, 89-1 Enya-cho, Izumo, Shimane 693-8501, Japan

E-mail: toda@med.shimane-u.ac.jp

Key words: cardiopulmonary bypass, deep hypothermic circulatory arrest, proteomics, complement activation, biocompatibility as cardiac function becomes unstable with the decrease in temperature. Profound $\left(<20^{\circ} \mathrm{C}\right)$ to deep $\left(<25^{\circ} \mathrm{C}\right)$ hypothermic circulatory arrest (HCA) combined with antegrade selective cerebral perfusion (SCP) is a protective strategy against brain ischemia in complex aortic surgery (1). Although there is relatively little evidence of adverse effects of profound/deep hypothermia, there is some concern that HCA may have some drawbacks, such as coagulation disorders $(2,3)$. As a consequence, moderate $\mathrm{HCA}\left(25-28^{\circ} \mathrm{C}\right)$ combined with increased SCP flow rates for aortic surgery has been utilized as the mainstay of treatment (4).

The development of isobaric tag-based quantitative mass spectrometry has provided a reliable method for high-throughput analysis of proteomes (5). Proteomic changes in human plasma samples have been successfully analyzed through the use of the isobaric tag for relative and absolute quantification (iTRAQ) labeling strategy $(6,7)$. In the present study, a comparison was made of the plasma proteomes of patients undergoing aortic surgery using deep hypothermic circulatory arrest (DHCA) and SCP (DHCA + SCP) to those undergoing aortic surgery using normothermic $\mathrm{CPB}$.

\section{Patients and methods}

Patient selection. The present prospective cohort study received approval from the Ethics Committee of Shimane University Faculty of Medicine and was conducted at Shimane University Hospital. The patients provided written informed consent. Patients with annulo-aortic ectasia, and ascending or aortic arch aneurysms were included in this study.

Anesthesia. The same anesthesia and CPB protocols were used for all patients: anesthesia was induced and maintained with fentanyl (15-20 $\mu \mathrm{g} / \mathrm{kg}$, administered intravenously prior to initiation of CPB) and propofol (3-6 mg/kg/h). Catecholamines, vasodilators and antiarrhythmic drugs were administered in a similar manner in the two groups of patients.

$C P B$. The cardiopulmonary circuit was the same for the two groups, consisting of a hollow-fiber polymer-coated membrane oxygenator (QUADROX-I, HMO70000; Maquet, Rastatt, Germany), heparin-coated venous reservoir (HVR-4WF; Mera, 
Tokyo, Japan) and polymer-coating cardiotomy reservoir (only used in hypothermic CPB; BO-HC2821; Maquet), centrifugal pump (ROTAFLOW, BO-RF32; Maquet), arterial filter (40 $\mu \mathrm{m}$ Pall arterial line filter, AL6; Pall, Port Washington, NY, USA) and heparin-coated CPB circuit (Mera or JMS, Tokyo, Japan). The pump was primed with bicarbonated Ringer's solution, mannitol and methylprednisolone $(500 \mathrm{mg})$. After systemic anticoagulation with $3 \mathrm{mg} / \mathrm{kg}$ heparin, CPB was instituted at a flow rate of $2.0-2.8 \mathrm{l} / \mathrm{min} / \mathrm{M}^{2}$. Blood gases, electrolytes, glucose and the hemoglobin $(\mathrm{Hb})$ concentration were continuously monitored by CDI 500 (Terumo, Tokyo, Japan) and blood gas analysis was performed every $30 \mathrm{~min}$ (ABL800 FLEX Blood Gas Analyzer; Radiometer, Copenhagen, Denmark). Each parameter was maintained as follows: $\mathrm{PaO}_{2}$ : $300-500 \mathrm{mmHg}, \mathrm{PaCO}_{2}: 35-45 \mathrm{mmHg}(\alpha$-stat management), blood glucose: $100-300 \mathrm{mg} / \mathrm{dl}, \mathrm{Hb}: 7-9 \mathrm{~g} / \mathrm{dl}$ in the two groups. Rectal and urinary bladder temperatures were monitored. Dilutional ultrafiltration was continuously performed during $\mathrm{CPB}$ for the patients in the two groups to correct hyperkalemia and fluid imbalance (Blood concentrator PLUS, BC-140 plus; Maquet). In DHCA $+\mathrm{SCP}$, the body was cooled to $22^{\circ} \mathrm{C}$ with topical head cooling. After cardioplegic cardiac arrest and initiation of HCA, SCP was performed following cannulation into the three arch vessels and maintained by monitoring pressures (both bilateral radial artery and SCP cannula tip) and using an INVOS Oximeter (INVOS 5100C; Somanetics, Troy, MI, USA). Rewarming was initiated following completion of open distal anastomosis and initiation of distal perfusion.

Blood sampling. Three blood samples were collected from an arterial line into ethylenediaminetetraacetic acid (EDTA) tubes as follows: T1 (before cooling, 5 min after pump initiation), T2 (before aortic declamping, 30-160 min after pump initiation in normothermic CPB or during deep hypothermia, 30-124 min after pump initiation in DHCA + SCP), T3 (just before termination of CPB, 90-193 min after pump initiation in normothermic CPB or 121-314 min after pump initiation in DHCA + SCP). Blood samples were centrifuged at $1,400 \times \mathrm{g}$ for $5 \mathrm{~min}$, and the plasma layers were stored at $-80^{\circ} \mathrm{C}$.

Immunodepletion of abundant proteins. The two most abundant plasma proteins, albumin and immunoglobulin (Ig) G, were removed using an immunodepletion column (Albumin \& IgG Depletion SpinTrap; GE Healthcare, Buckinghamshire, UK) according to the manufacturer's instructions and as previously described (7).

iTRAQ labeling and strong cation exchange (SCX) chromatography. Samples were prepared according to the manual published by AB Sciex (Foster city, CA, USA) and as described previously (7). In brief, equal amounts of immunodepleted T1, $\mathrm{T} 2$, and $\mathrm{T} 3$ samples from each patient were denaturated and reduced, the cysteines were alkylated, and then digested with trypsin (AB Sciex). Each digest was labeled with a different iTRAQ tag using the iTRAQ reagent 4-plex kit (AB Sciex). iTRAQ label 114 was used for the T1 sample, and iTRAQ labels 115,116 or 117 were randomly selected for the T2 and T3 samples, after which the three samples of each patient were combined. The combined samples were then fractionated into six fractions by SCX chromatography according to the manufacturer's instructions (AB Sciex) and each fraction was desalted according to the manufacturer's instructions (Waters, Milford, MA, USA).

NanoLC and MALDI-TOF/TOF MS/MS analysis. One fraction from the SCX chromatography (see above) was fractionated to 171 spots using a DiNa nanoLC system (KYA Technologies, Tokyo, Japan) and collected onto an Opti-TOF LC/MALDI 384 target plate (AB Sciex) according to the manufacturer's instructions and as previously described (7). Spotted peptide samples were analyzed by a $5800 \mathrm{MALDI}-\mathrm{TOF} / \mathrm{TOF}$ MS/MS Analyzer with TOF/TOF Series software (version 4.0; AB Sciex). MS/MS data were analyzed using ProteinPilot ${ }^{\mathrm{TM}}$ software (version 3.0) and the Paragon ${ }^{\mathrm{TM}}$ protein database (AB Sciex). Quantitative changes of proteins at T2 or T3 were calculated using the iTRAQ ratios T2:T1 or T3:T1, respectively.

iTRAQ data analysis and bioinformatic analysis. Proteins identified as showing expression changes were tested for conformity to the following conditions: i) a false discovery rate (FDR) $<5 \%$ (FDR was estimated by 'decoy database searching' using the ProteinPilot Software); and ii) protein confidence $>99 \%$ ('unused ProtScore' $>2$ ). Unused ProtScore is defined as $-\log (1-\%$ confidence/100). Proteins fulfilling these criteria were considered to have 'statistical significance' $(7,8)$. PANTHER software (version 8.1, http://www.pantherdb. org) was used to test for statistical overrepresentation of Gene Ontology (GO, http://www.geneontology.org) terms as described in detail elsewhere $(9,10)$. If the number of identified genes in a GO term was significantly larger than that in the whole genome classified by the same GO term, i.e., the number of observed genes in a GO term is significantly larger than the number of expected genes in the same GO term by the binomial test, the GO term was described here as 'overrepresented' with statistical significance after a Bonferroni correction for multiple testing. The annotations of identified proteins were obtained from the Uniprot database (http://www.uniprot.org/).

Western blot analysis and enzyme-linked immunosorbent assay (ELISA). Western blot analyses were performed as described previously (7). In brief, plasma samples were separated by sodium dodecyl sulfate-polyacrylamide gel electrophoresis (SDS-PAGE), and immunoblotted using rabbit monoclonal carbonic anhydrase 1 (CA1) antibody (Abcam, Tokyo, Japan) and anti-rabbit IR dye 680-conjugated IgG (LI-COR, Lincoln, NE, USA). Protein bands were visualized using an Odyssey (LI-COR) infrared imaging system and their intensities measured for densitometric analyses of CA1. Plasma levels of the complement proteins C5a and SC5b-9 were determined using a commercially available solid-phase sandwich ELISA kit (Quidel Corp., San Diego, CA, USA) following the manufacturer's recommendations.

Statistical analysis. Continuous variables, such as blood gas analysis and hemodynamic variables were expressed as means \pm standard deviation (SD). The variables were tested for statistically significant differences between patient groups using the Student's t-test. Categorical variables were compared using Fisher's exact test. For analysis of iTRAQ ratios, i.e. T2:T1 or T3:T1 ratios for each significantly identified protein, $\mathrm{P}$-values 
were calculated by the one sample t-test of averaged protein ratio against 1 to assess the validity of the protein expression change (11). To assess ELISA and western blot analysis data, statistical comparisons were performed by two-way analysis of variance (ANOVA) (general linear model) with repeated measures followed by a post-hoc Bonferroni test to detect individual differences. The relationships between complement activation (SC5b-9) and the iTRAQ ratios of each protein including CA1 values (western blot analysis) were calculated by single and stepwise multiple regression analyses (forward selection method) (StatFlex version 6; Artech, Osaka, Japan). $\mathrm{P}<0.05$ was considered to indicate statistical significance.

\section{Results}

Patient characteristics and CPB data. Baseline characteristics were similar in both groups except for minimal core temperature and CPB time (Table I). There were several small but significant differences in blood gas analysis, $\mathrm{Hb}$ and lactate levels in both groups (Table II). Pump flow rate, perfusion pressure, and core temperatures were similar between the two groups at T1 and T3. At T2, there was a significant difference in core temperature between the two groups: $23.0 \pm 1.2^{\circ} \mathrm{C}$ vs. $36.0 \pm 1.0^{\circ} \mathrm{C}(\mathrm{P}<0.0001)$. The timing of $\mathrm{T} 1$ and $\mathrm{T} 2$ sampling from the initiation of $\mathrm{CPB}$ did not differ between the two groups $(\mathrm{P}=1.000$ for $\mathrm{T} 1, \mathrm{P}=0.250$ for $\mathrm{T} 2)$; however, sampling at T3 was performed significantly later in the DHCA + SCP patient group than in the normothermic CPB group (Table I). The HCA time of the lower body averaged $59 \pm 41 \mathrm{~min}$ in DHCA + SCP patients.

iTRAQ data analysis and bioinformatics. Mass spectrometry identified 322 proteins, of which 262 were found to be statistically significant, i.e., the proteins fulfilled both the FDR $<5 \%$ and protein confidence $>99 \%$ criteria. Of the 262 proteins, those that increased or decreased ( $>1.2$-fold or $<0.833$-fold) in at least four of the seven samples in each treatment group were identified to obtain an adequate sample size and statistical power $(5,12)$, subsequently analyzed by PANTHER software. The statistical overrepresentation test identified six GO categories (biological processes) with five proteins significantly increased in the normothermic CPB group at T2 (Tables III and V). By contrast, only one GO category showed significant overrepresentation in the DHCA + SCP group at T2 (Table III). At T3 in the latter treatment group, $11 \mathrm{GO}$ categories were significantly overrepresented with 48 proteins significantly decreased, whereas only one GO category was significantly overrepresented in the normothermic CPB group (Tables IV and VI). In the normothermic CPB group, the iTRAQ ratio of CA1 increased significantly to $1.50 \pm 0.23$ at $\mathrm{T} 2$ and to $1.58 \pm 0.30$ at $\mathrm{T} 3$ in comparison to $\mathrm{T} 1(\mathrm{P}=0.0241$ at $\mathrm{T} 2$, and $\mathrm{P}=0.0299$ at $\mathrm{T} 3$, Table $\mathrm{V})$. The ratio also increased in the DHCA + SCP group to $1.52 \pm 0.45$ at T2 and $2.65 \pm 1.65$ at T3, although without statistical significance due to missing data. This increase in the CA1 ratio at T3 is a noteworthy finding as all other proteins decreased significantly in the DHCA + SCP patients, with the exception of HBA1 and HBB (Table VI).

Western blot analysis and ELISA. To validate the ITRAQ ratios and complement activation identified by the PANTHER analysis, the protein CA1 was analyzed by western blot analysis and
Table I. Baseline characteristics, type of surgery and intraoperative variables.

\begin{tabular}{lccr}
\hline Variables & $\begin{array}{c}\text { Normothermic } \\
\text { CPB }(\mathrm{n}=7)\end{array}$ & $\begin{array}{c}\text { DHCA }+ \text { SCP } \\
(\mathrm{n}=7)\end{array}$ & P-value \\
\hline Age & $66.0 \pm 8.8$ & $69.9 \pm 7.0$ & 0.3841 \\
$\begin{array}{l}\text { Gender } \\
\text { (male) }\end{array}$ & 3 & 4 & 1.0000 \\
$\begin{array}{l}\text { B-blocker } \\
\text { ACEIs/ARBs }\end{array}$ & 1 & 4 & 0.2657 \\
$\begin{array}{l}\text { Calcium } \\
\text { channel blockers }\end{array}$ & 2 & 6 & 0.1026 \\
$\begin{array}{l}\text { Oral } \\
\text { antihypoglycemic agent }\end{array}$ & 1 & 5 & 0.5921 \\
$\begin{array}{l}\text { Statins } \\
\text { Minimal core } \\
\text { temperature }\left({ }^{\circ} \mathrm{C}\right)\end{array}$ & 4 & 0 & 1.0000 \\
$\begin{array}{l}\text { Aortic cross-clamping } \\
\text { time (min) }\end{array}$ & $107.0 \pm 31.7$ & $117.7 \pm 68.6$ & 0.7245 \\
CPB time (min) & $142.9 \pm 34.2$ & $218.7 \pm 75.7$ & 0.0457 \\
\hline
\end{tabular}

ACEI, angiotension converting enzyme inhibitor; ARB, angiotensin II receptor blocker; $\mathrm{CPB}$, cardiopulmonary bypass; $\mathrm{DHCA}+\mathrm{SCP}$, deep hypothermic circulatory arrest with selective cerebral perfusion.

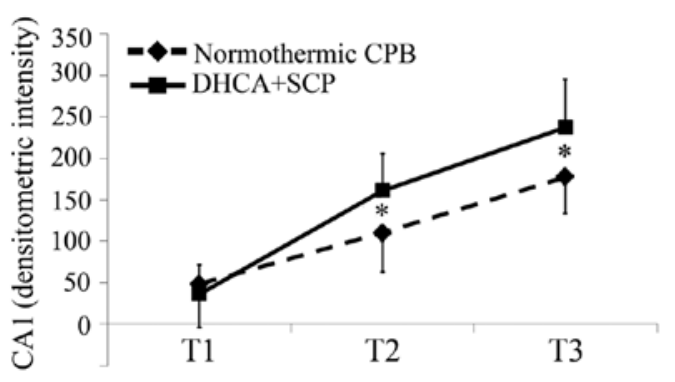

Figure 1. Results of the western blot analysis of carbonic anhydrase 1 (CA1) levels during cardiopulmonary bypass (CPB). CA1 levels increased significantly with time during $\mathrm{CPB}\left({ }^{*} \mathrm{P}<0.0001\right)$ in the deep hypothermic circulatory arrest (DHCA) and selective cerebral perfusion (SCP) (DHCA + SCP) and normothermic $\mathrm{CPB}$ patients with no significant differences between the two groups. "Significant differences $(\mathrm{P}<0.0001)$ between sampling times in the two groups. T1, 5 min after initiation of CPB; T2, during deep hypothermia or before declamping; T3, just before termination of $\mathrm{CPB}$.

the complement proteins C5a and SC5b-9 were measured by ELISA. In both patient groups, the levels of CA1 continuously and significantly increased during $\mathrm{CPB}(\mathrm{P}<0.0001)$, although the differences between the groups were not significant (Fig. 1). The level of complement C5a increased, albeit non-significantly, at $\mathrm{T} 3$ in the DHCA + SCP group compared to the normothermic group (Fig 2A). The level of SC5b-9 increased significantly at $\mathrm{T} 2$ in the normothermic group, and the differences between $\mathrm{T} 1$ and T2 and between T1 and T3 were both highly significant $(\mathrm{P}<0.0001$, Fig 2B). In the DHCA + SCP group, the level of SC5b-9 increased slightly from T1 to T2, and then increased 
Table II. Arterial blood gas analysis at three sampling points during CPB for aortic surgery.

\begin{tabular}{|c|c|c|c|c|c|c|c|c|}
\hline Treatment methods & $\begin{array}{l}\text { Sampling } \\
\text { time }\end{array}$ & $\mathrm{pH}$ & $\begin{array}{c}\mathrm{PaO}_{2} \\
(\mathrm{mmHg})\end{array}$ & $\begin{array}{c}\mathrm{PaCO}_{2} \\
(\mathrm{mmHg})\end{array}$ & B.E. & $\begin{array}{c}\text { Glucose } \\
(\mathrm{mg} / \mathrm{dl})\end{array}$ & $\begin{array}{c}\text { Lactate } \\
(\mathrm{mmol} / \mathrm{l})\end{array}$ & $\begin{array}{r}\mathrm{Hb} \\
(\mathrm{g} / \mathrm{dl})\end{array}$ \\
\hline \multirow{3}{*}{ Normothermic CPB } & $\mathrm{T} 1$ & $7.38 \pm 0.05$ & $387 \pm 49$ & $41.5 \pm 4.5$ & $-1.1 \pm 2.0$ & $99 \pm 20$ & $10.0 \pm 4.7$ & $7.4 \pm 0.9$ \\
\hline & $\mathrm{T} 2$ & $7.35 \pm 0.03$ & $399 \pm 33$ & $45.0 \pm 2.0^{\mathrm{a}}$ & $-1.1 \pm 2.4$ & $125 \pm 18$ & $10.0 \pm 5.9$ & $8.7 \pm 1.3^{\mathrm{b}}$ \\
\hline & $\mathrm{T} 3$ & $7.37 \pm 0.04$ & $373 \pm 35^{c}$ & $43.0 \pm 1.8$ & $-0.6 \pm 1.6^{\mathrm{d}}$ & $124 \pm 23$ & $10.7 \pm 7.3^{\mathrm{e}}$ & $8.3 \pm 1.4$ \\
\hline \multirow{3}{*}{$\mathrm{DHCA}+\mathrm{SCP}$} & $\mathrm{T} 1$ & $7.38 \pm 0.03$ & $390 \pm 38$ & $41.4 \pm 2.6$ & $-0.8 \pm 1.9$ & $114 \pm 21$ & $12.0 \pm 4.9$ & $7.1 \pm 0.6$ \\
\hline & $\mathrm{T} 2$ & $7.32 \pm 0.04$ & $424 \pm 43$ & $49.7 \pm 3.9^{\mathrm{a}}$ & $-0.9 \pm 3.2$ & $96 \pm 33$ & $15.1 \pm 5.9$ & $6.7 \pm 0.6^{\mathrm{b}}$ \\
\hline & $\mathrm{T} 3$ & $7.35 \pm 0.03$ & $321 \pm 28^{c}$ & $43.0 \pm 3.6$ & $-2.3 \pm 0.8^{\mathrm{d}}$ & $140 \pm 47$ & $24.9 \pm 12.9^{\mathrm{e}}$ & $7.6 \pm 0.6$ \\
\hline
\end{tabular}

Statistically significant differences between the two groups were: ${ }^{\mathrm{a} P}=0.0157,{ }^{\mathrm{b}} \mathrm{P}=0.0058,{ }^{\mathrm{C}} \mathrm{P}=0.0102,{ }^{\mathrm{d}} \mathrm{P}=0.0297,{ }^{\mathrm{e}} \mathrm{P}=0.0270$. B.E., base excess; $\mathrm{CPB}$, cardiopulmonary bypass; DHCA, deep hypothermic circulatory arrest; Hb, hemoglobin concentration; SCP, selective cerebral perfusion; T1, 5 min after initiation of $\mathrm{CPB}$; $\mathrm{T} 2$, during deep hypothermia or declamping; $\mathrm{T} 3$, just before termination of $\mathrm{CPB}$.

Table III. GO categories showing significant overrepresentation for plasma proteins at T2.

\begin{tabular}{|c|c|c|c|c|c|c|}
\hline \multirow[b]{2}{*}{ GO term } & \multirow[b]{2}{*}{ Description } & \multicolumn{3}{|c|}{ Homo sapiens } & \multicolumn{2}{|c|}{ Plasma sample } \\
\hline & & $\begin{array}{l}\text { No. of } \\
\text { genes }\end{array}$ & $\begin{array}{c}\text { No. of } \\
\text { observed genes }\end{array}$ & $\begin{array}{c}\text { No. of } \\
\text { expected genes }\end{array}$ & P-value & Genes \\
\hline
\end{tabular}

A, Normothermic CPB

\begin{tabular}{|c|c|c|c|c|c|c|}
\hline 0006956 & $\begin{array}{l}\text { Complement } \\
\text { activation }\end{array}$ & 99 & 6 & 0.09 & $6.46 \mathrm{E}-08$ & C8B C1S C1R C6 C4B C5 \\
\hline 0006508 & Proteolysis & 1,131 & 10 & 1.07 & 3.29E-06 & $\begin{array}{l}\text { C8B SERPING1 ITIH3 C1S C1R C6 C4B C5 } \\
\text { SERPINA4 AGT }\end{array}$ \\
\hline 0006955 & Immune response & 725 & 7 & 0.69 & 4.82E-04 & C8B AZGP1 C1S C1R C6 C4B C5 \\
\hline 0007596 & Blood coagulation & 271 & 4 & 0.26 & $1.90 \mathrm{E}-02$ & C8B C1S C1R C6 \\
\hline 0009605 & $\begin{array}{l}\text { Response to } \\
\text { external stimulus }\end{array}$ & 271 & 4 & 0.26 & $1.90 \mathrm{E}-02$ & C8B C1S C1R C6 \\
\hline 0019538 & $\begin{array}{l}\text { Protein metabolic } \\
\text { process }\end{array}$ & 3,178 & 10 & 3.02 & 4.02E-02 & $\begin{array}{l}\text { C8B SERPING1 ITIH3 C1S C1R C6 C4B C5 } \\
\text { SERPINA4 AGT }\end{array}$ \\
\hline
\end{tabular}

$\mathrm{B}, \mathrm{DHCA}+\mathrm{SCP}$

0006869 Lipid transport $\quad 220 \quad 3 \quad 0.12 \quad 3.52 \mathrm{E}-02 \quad$ APOD APOC3 APOA2

The test for statistical overrepresentation of each Gene Ontology (GO) term (biological process) was perfomed using PANTHER software (version 8.1). Upregulated genes are shown in bold. ${ }^{a}$ The total number of genes in the whole genomes (Homo sapiens, $\left.\mathrm{n}=20,000\right)$ classified by the GO term; ${ }^{\text {b }}$ the number of genes from the input list [n=20 (mapped genes, 19; unmapped gene, 1 ) in the normothermic cardiopulmonary bypass (CPB) group, $\mathrm{n}=12$ (mapped genes, 11; unmapped gene, 1)' in the deep hypothermic circulatory arrest (DHCA) with selective cerebral perfusion (SCP) group (DHCA + SCP)] classified by the GO term; ${ }^{c}$ the number of genes that would be detected in the input list for a particular GO category on the basis of the reference list (Homo sapiens). T2, during deep hypothermia or before declamping.

rapidly and significantly from $\mathrm{T} 2$ to $\mathrm{T} 3$. There were significant differences in SC5b-9 values between T3 and T1 and between $\mathrm{T} 3$ and $\mathrm{T} 2$ in the DHCA + SCP group $(\mathrm{P}<0.0001)$, and between both groups at $\mathrm{T} 2$, respectively $(\mathrm{P}=0.008)$. Since the innate immunity response is regulated by complex protein-protein interactions (13), it is difficult to clarify the causative relationship between the SC5b-9 level and iTRAQ ratios of identified proteins. Therefore, single regression analyses were performed to search for the relationships between the SC5-9 values and the iTRAQ ratios of the 42 proteins identified in all samples including the CA1 value (western blot analysis). Seven proteins (CP, HPX, VTN, F2, A1BG, GC, and CA1) showed significant correlations with SC5b-9 levels. A stepwise multiple regression analysis identified a significant coefficient $(\mathrm{R}=0.486)$ and ceruloplasmin as an independent variable (standardized $\beta=-0.468, P=0.012$ ).

\section{Discussion}

Exposure of blood components to a CPB circuit activates various blood cell types, endothelial cells and proteins. This activation can improperly stimulate biological processes that may 
Table IV. GO categories showing significant overrepresentation for plasma proteins at T3.

\begin{tabular}{|c|c|c|c|c|c|c|}
\hline \multirow[b]{2}{*}{ GO term } & \multirow[b]{2}{*}{ Description } & \multicolumn{3}{|c|}{ Homo sapiens } & \multicolumn{2}{|c|}{ Plasma sample } \\
\hline & & $\begin{array}{l}\text { No. of } \\
\text { genes }^{\text {a }}\end{array}$ & $\begin{array}{c}\text { No. of } \\
\text { observed } \\
\text { genes }^{\mathrm{b}}\end{array}$ & $\begin{array}{c}\text { No. of } \\
\text { expected } \\
\text { genes }^{c}\end{array}$ & P-value & Genes \\
\hline
\end{tabular}

A, Normothermic CPB

\begin{tabular}{|c|c|c|}
\hline 0008015 & Blood circulation & 192 \\
\hline
\end{tabular}

$\mathrm{B}, \mathrm{DHCA}+\mathrm{SCP}$

\begin{tabular}{|c|c|c|c|c|c|c|}
\hline 0006508 & Proteolysis & 1131 & 22 & 2.94 & $3.13 \mathrm{E}-12$ & $\begin{array}{l}\text { SERPING1 PLG SERPINC1 APOH C3 ITIH1 F2 CP A2M } \\
\text { C4BPA C4B CFB HP SERINF2 CFH ITIH2 C5 AHSG } \\
\text { SERPINA3 ITIH4 AMBP SERPINA1 }\end{array}$ \\
\hline 0006956 & $\begin{array}{l}\text { Complement } \\
\text { activation }\end{array}$ & 99 & 10 & 0.26 & $1.98 \mathrm{E}-11$ & APOH C3 PGLYRP2 A2M C4BPA C4B CFB CFH HP C5 \\
\hline 0007596 & Blood coagulation & 271 & 10 & 0.7 & $3.36 \mathrm{E}-07$ & APOH F2 CP C4BPA CFB CFH HP TF HRG AMBP \\
\hline 0009605 & $\begin{array}{l}\text { Response to } \\
\text { external stimulus }\end{array}$ & 271 & 10 & 0.7 & $3.36 \mathrm{E}-07$ & APOH F2 CP C4BPA CFB CFH HP TF HRG AMBP \\
\hline 0006955 & Immune response & 725 & 12 & 1.88 & 4.68E-05 & $\begin{array}{l}\text { A1BG APOH C3 PGLYRP2 A2M C4BPA C4B CFB CFH } \\
\text { HP TF C5 }\end{array}$ \\
\hline 0050896 & $\begin{array}{l}\text { Response to } \\
\text { stimulus }\end{array}$ & 1767 & 17 & 4.59 & $2.20 \mathrm{E}-04$ & $\begin{array}{l}\text { A1BG APOH C3 PGLYRP2 F2 CP A2M C4BPA CFB } \\
\text { C4B HP CFH TF C5 HRG AMBP }\end{array}$ \\
\hline 0002376 & $\begin{array}{l}\text { Immune system } \\
\text { process }\end{array}$ & 2480 & 20 & 6.45 & 2.92E-04 & $\begin{array}{l}\text { A1BG APOH C3 PGLYRP2 F2 CP A2M C4BPA CFB } \\
\text { C4B HP CFH TF C5 SAA4 AHSG HRG AMBP }\end{array}$ \\
\hline 0019538 & $\begin{array}{l}\text { Protein metabolic } \\
\text { process }\end{array}$ & 3178 & 22 & 8.26 & $9.02 \mathrm{E}-04$ & $\begin{array}{l}\text { SERPING1 PLG SERPINC1 APOH C3 ITIH1 F2 CP A2M } \\
\text { C4BPA C4B CFB HP SERINF2 CFH ITIH2 C5 AHSG } \\
\text { SERPINA3 ITIH4 AMBP SERPINA1 }\end{array}$ \\
\hline 0006869 & Lipid transport & 220 & 7 & 0.57 & $2.89 \mathrm{E}-04$ & APOB APOD APOA1 APOE APOC3 APOA2 APOL1 \\
\hline 0016337 & Cell-cell adhesion & 724 & 9 & 1.88 & $1.63 \mathrm{E}-02$ & APOH FGB CP C4BPA FGG CFB CFH FGA VTN \\
\hline 0006810 & Vitamin transport & 90 & 4 & 0.23 & $1.60 \mathrm{E}-02$ & TTR CP HPX RBP4 \\
\hline
\end{tabular}

The test for statistical overrepresentation of each Gene Ontology (GO) term (biological process) was perfomed using PANTHER software (version 8.1). Upregulated genes are shown in bold. ${ }^{a}$ The total number of genes in the whole genomes (Homo sapiens, $\mathrm{n}=20,000$ ) classified by the GO term; ${ }^{b}$ the number of genes from the input list [ $\mathrm{n}=11$ (mapped genes, 11) in the normothermic cardiopulmonary bypass (CPB) group, n=57 (mapped genes, 52 ; unmapped gene, 5)

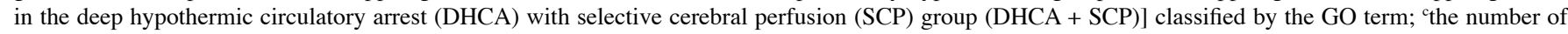
genes that would be detected in the input list for a particular GO category on the basis of the reference list (Homo sapiens). T3, just before termination of CPB.

contribute to the development of postoperative complications resulting from the dysfunction of blood cells, coagulation, fibrinolysis, and the kinin-kallikrein and immune systems (14-16). Various modifications to the inner surface of the CPB circuit, including heparin- and polymer-coating, reduce adverse effects on complement activation, blood coagulation, proinflammatory cytokines and improve clinical outcomes (17-20). The C5 complement inhibitor pexelizumab and a complement factor 1 esterase inhibitor have been tested clinically (21) and in an animal study (22) for their abilities to reduce complement activation during CPB. Although a recent proteomic study demonstrated the possibility of identifying predictive plasma biomarkers in patients undergoing CPB (23), this approach has not been used to investigate the effect of hypothermia/rewarming on the biocompatibility of a CPB circuit.
The proteins that were identified as showing significant protein confidence in this experiment were all included in the list of proteins reported previously for the human plasma proteome (24). Our analysis using iTRAQ labeling mass spectrometry demonstrated that several GO categories related to the complement system and proteolysis were significantly overrepresented at $\mathrm{T} 2$ in normothermic $\mathrm{CPB}$ in spite of using a heparin-coated $\mathrm{CPB}$ circuit and polymer-coated oxygenator. Of note, these changes were not observed at T2 in DHCA + SCP patients. To confirm these findings, the levels of plasma C5a and SC5b-9 were measured by ELISA, which showed a significantly larger increase in SC5b-9 at T2 in patients undergoing normothermic CPB compared to DHCA $+\mathrm{SCP}$. This reduction in the complement activation level in the DHCA + SCP group is similar to the findings from investigations of a randomized 
Table V. Plasma proteins showing significantly changed iTRAQ ratio at $\mathrm{T} 2$ or $\mathrm{T} 3$ of normothermic CPB.

\begin{tabular}{|c|c|c|c|c|c|c|c|c|c|c|}
\hline \multirow[b]{2}{*}{$\begin{array}{l}\text { Unused } \\
\text { ProtScore }\end{array}$} & \multirow[b]{2}{*}{$\begin{array}{c}\text { Coverage } \\
\%\end{array}$} & \multirow[b]{2}{*}{$\begin{array}{l}\text { Peptides } \\
(95 \%)\end{array}$} & \multirow[b]{2}{*}{$\begin{array}{l}\text { Uniprot } \\
\text { No. }\end{array}$} & \multirow[b]{2}{*}{ Gene } & \multirow[b]{2}{*}{ Protein } & \multicolumn{2}{|c|}{ At $T 2$} & \multicolumn{2}{|c|}{ At $\mathrm{T} 3$} & \multirow[b]{2}{*}{$\begin{array}{c}\text { Biological } \\
\text { process }(\mathrm{GO})\end{array}$} \\
\hline & & & & & & $\mathrm{T} 2 / \mathrm{T} 1^{\mathrm{b}}$ & P-value & $\mathrm{T} 3 / \mathrm{T} 1^{\mathrm{b}}$ & P-value & \\
\hline 33.33 & 96.6 & 39 & P68871 & $\mathrm{HBB}$ & Hb subunit $\beta$ & 4.07 & 0.0138 & 8.70 & 0.1023 & Oxygen transport \\
\hline 19.66 & 73.2 & 30 & P69905 & HBA1 & $\mathrm{Hb}$ subunit $\alpha$ & 3.79 & 0.0216 & 7.15 & 0.0536 & Oxygen transport \\
\hline 12.00 & 40.2 & 7 & P00915 & CA1 & $\mathrm{CA}^{\mathrm{a}}$ & 1.50 & 0.0241 & 1.58 & 0.0299 & Bicarbonate transport \\
\hline 23.29 & 35.0 & 12 & P05155 & SERPING1 & $\begin{array}{l}\text { Plasma protease } \\
\mathrm{C} 1 \text { inhibitor }\end{array}$ & 1.29 & 0.0088 & 1.13 & 0.2306 & $\begin{array}{l}\text { Complement activation, } \\
\text { blood coagulation }\end{array}$ \\
\hline 8.01 & 14.3 & 4 & P00736 & $\mathrm{C} 1 \mathrm{R}$ & $\begin{array}{l}\text { Complement C1r } \\
\text { subcomponent }\end{array}$ & 1.25 & 0.0227 & 1.13 & 0.3394 & Complement activation \\
\hline 31.70 & 32.4 & 19 & P04004 & VTN & $\mathrm{VTN}^{\mathrm{a}}$ & 1.03 & 0.5583 & 0.80 & 0.0026 & Innate immune response \\
\hline 12.01 & 38.1 & 9 & P02743 & APCS & $\begin{array}{l}\text { Serum amyloid } \\
\text { P-component }\end{array}$ & 1.07 & 0.5955 & 0.77 & 0.0006 & Acute-phase response \\
\hline 95.65 & 85.7 & 93 & P00738 & HP & Haptoglobin & 0.80 & 0.0716 & 0.62 & 0.0035 & $\begin{array}{l}\text { Acute-phase response, } \\
\text { defense response }\end{array}$ \\
\hline
\end{tabular}

Bold, increased ratio ( $\geq 1.2$-fold) with statistical significance and italics, decreased ratio $(\leq 0.83$-fold $)$ with statistical significance. Plasma samplings were performed at T1 [5 min after initiation of cardiopulmonary bypass (CPB)], T2 (before declamping) and T3 (just before termination of CPB). Unused ProtScore indicates protein confidence as expressed by the formula: ProtScore $=-\log (1-\%$ confidence/100). Coverage $\%$ indicates the percentage of matching amino acids

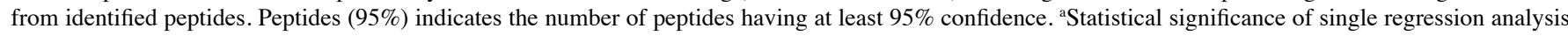
of relationships between isobaric tag for relative and absolute quantification (iTRAQ) ratios of proteins and SC5b-9 measured by enzyme-linked immunosorbent assay (ELISA); biTRAQ average ratio. CA1, carbonic anhydrase 1; GO, Gene Ontology; Hb, hemoglobin; VTN, vitronectin.
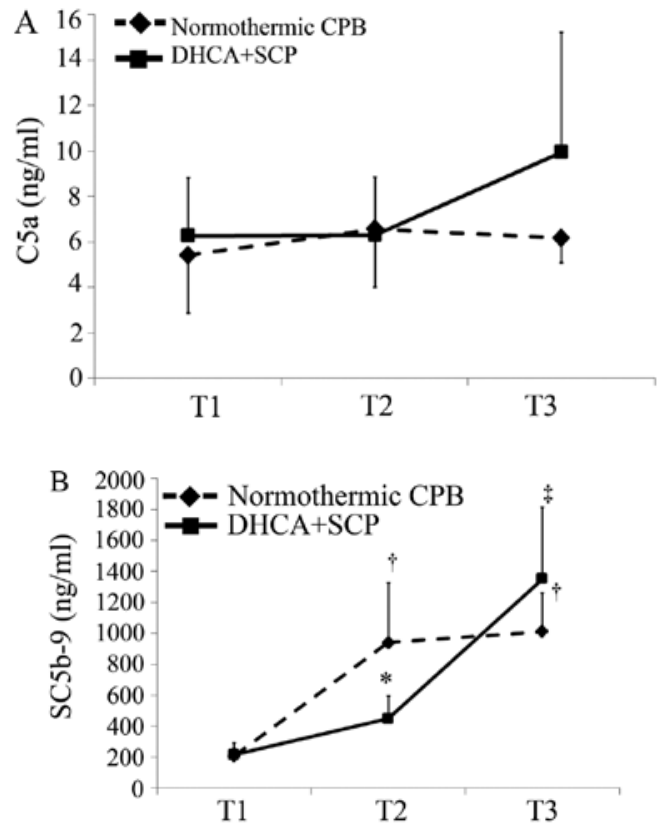

Figure 2. Enzyme-linked immunosorbent assay (ELISA) analyses of complement levels during cardiopulmonary bypass (CPB). (A) Levels of C5a increased non-significantly at $\mathrm{T} 3$ in deep hypothermic circulatory arrest (DHCA) and selective cerebral perfusion (SCP) (DHCA + SCP patients. (B) Levels of SC5b-9 increased rapidly and significantly at T2 and, thereafter, were relatively unchanged at $\mathrm{T} 3$ in normothermic CPB patients. Conversely, SC5b-9 increased slightly at T2, but then increased rapidly and significantly at T3 in DHCA + SCP patients. There was a significant difference ( $\mathrm{P}=0.008$ ) between the two patient groups at $\mathrm{T} 2$; additionally, the normothermic CPB showed significant differences $(\mathrm{P}<0.0001)$ between $\mathrm{T} 2$ and $\mathrm{T} 1$, and between $\mathrm{T} 3$ and $\mathrm{T} 1 ; \mathrm{DHCA}+\mathrm{SCP}$ patients showed significant differences $\left({ }^{\star} \mathrm{P}<0.0001\right)$ between $\mathrm{T} 3$ and $\mathrm{T} 2$, and between $\mathrm{T} 3$ and $\mathrm{T} 1$. Sampling times are identical to those in Fig. 1.
CPB study or therapeutic hypothermia for encephalopathy, which showed that hypothermia can suppress the immune response (25-27). In this context, our previous proteomic analysis of rat liver samples after a short duration ( $3 \mathrm{~h}$ ) of deep hypothermia $\left(23^{\circ} \mathrm{C}\right)$ demonstrated that 264 proteins changed significantly with 163 showing a decrease (28). Consequently, the deep hypothermia $\left(22^{\circ} \mathrm{C}\right)$ and circulatory arrest of the lower body that occurs in DHCA + SCP might further decrease complement components (activators and regulators) that are mainly produced in the liver. Any such decrease may have a significant effect on the activity of the complement system at $\mathrm{T} 2$ in the DHCA + SCP patients.

Complement activation in the DHCA + SCP group was indicated by the rapid increase in the level of SC5b-9 from $\mathrm{T} 2$ to T3. To the best of our knowledge, this is the first study to demonstrate that CPB-induced complement activation can be initially suppressed at $\mathrm{T} 2$ and later upregulated at $\mathrm{T} 3$ in the DHCA + SCP group. The latter response may in part have occurred because complement activation can develop after rewarming. This explanation is supported by a study on mild hypothermia after cardiac arrest which demonstrated that complement activation decreased after the induction of hypothermia $\left(32-34^{\circ} \mathrm{C}\right)$, followed by an increase during rewarming (27). Another possible cause of complement activation at T3 may be reperfusion injury of the lower part of the body that developed with the lactate production at T3 (Table II), which may indicate that the metabolism of lower body had been conducted anaerobically with the production of oxygen debt during $59 \pm 41 \mathrm{~min}$ of DHCA in the DHCA + SCP group (29). Moreover, rewarming has been shown to aggravate cold-induced $\left(4^{\circ} \mathrm{C}\right)$ oxidative hepatocyte injury caused 


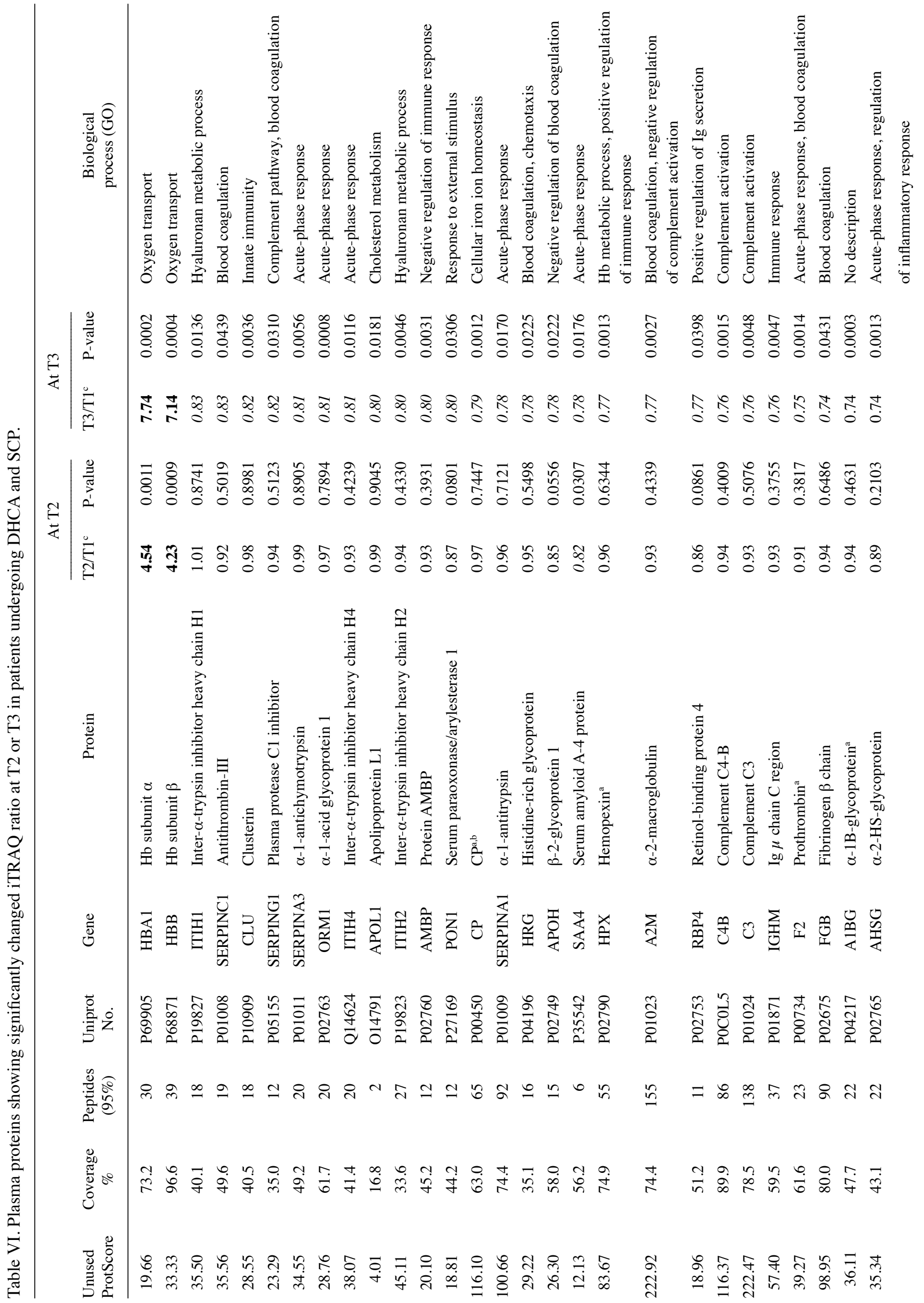




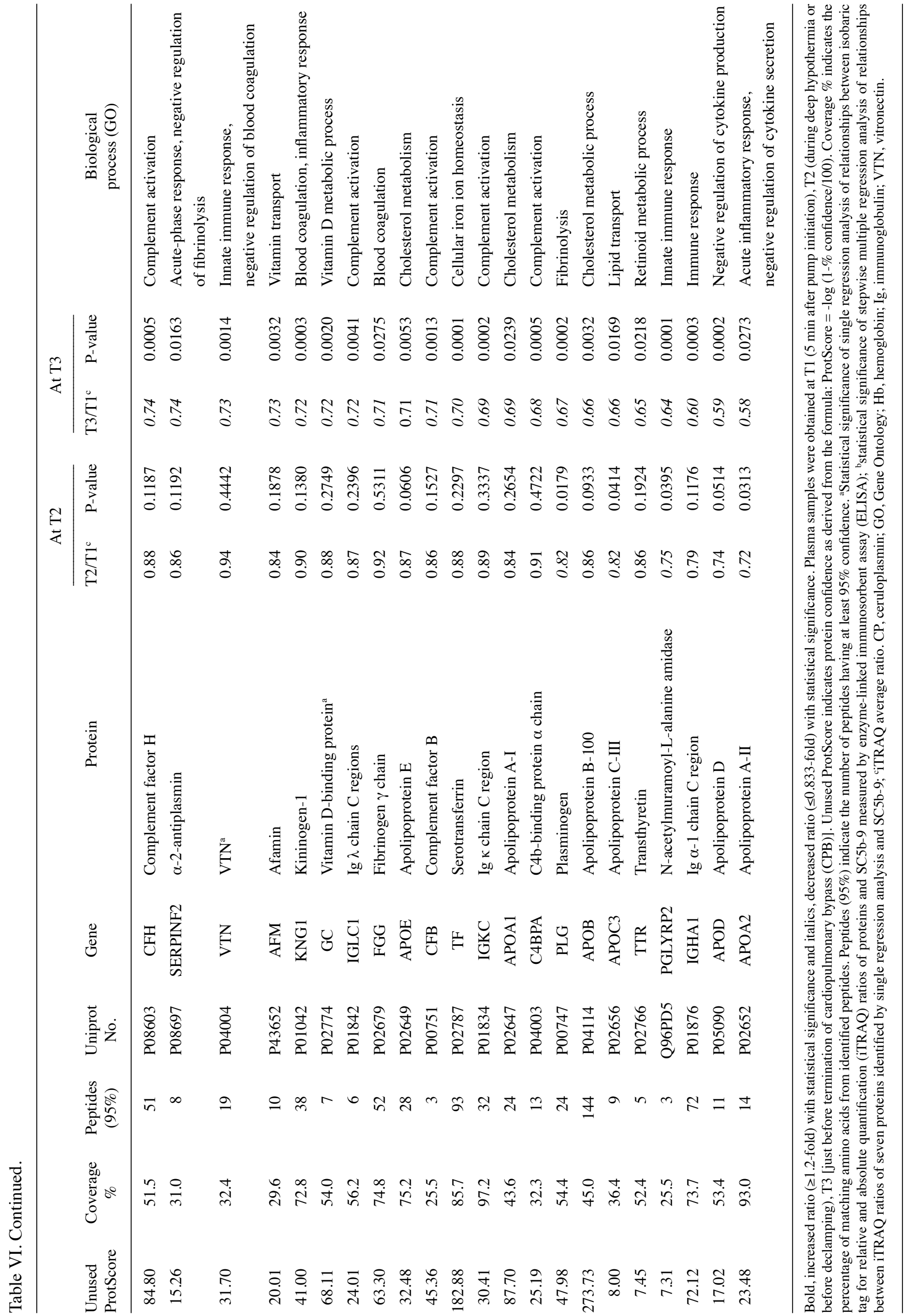


by chelatable iron via Fenton chemistry and, thereby, to accelerate complement activation (30). On the other hand, both reperfusion injury and the impact of cooling/rewarming on liver metabolism may underlie the downregulation of some of the identified proteins at T3. A number of proteins were found to be downregulated at $\mathrm{T} 3$ in the DHCA + SCP patients (Tables IV and VI). This downregulation seems inconsistent with the complement activation identified by the ELISA analysis. Possibly, this inconsistency might be explained by the tight control of complement activation by its regulators, suggesting that the downregulation of regulators such as vitronectin (VTN) or C1-inhibitor (SERPING1) contribute to complement activation (Table VI) (29). CA1 had a significant positive correlation with SC5b-9 levels by a single regression analysis. It has been demonstrated that CA1 causes kallikrein-kinin system activation (31). There is evidence of an interaction among the complement, coagulation and kinin systems $(29,32)$ in which kallikrein is an initiator of the complement cascade by digestion of factor XIIa into factor XIIf (33) and possibly through the cleavage of C3 or C5 into active forms (32). By contrast, ceruloplasmin, which had a significant negative correlation with the SC5b-9 level by stepwise multiple regression analysis, was downregulated at $\mathrm{T} 3$ in the DHCA + SCP. This protein has ferroxidase activity to oxidize $\mathrm{Fe}^{2+}$ to $\mathrm{Fe}^{3+}$, contributing to the antioxidant capacity because of the reduction of oxidation capacity via the Fenton reaction (34). Ceruloplasmin is also reported to be an endogenous inhibitor of myeloperoxidase (35), but is downregulated by reactive oxygen species (34). Taken together, $\mathrm{CA} 1$, an upregulated protein at $\mathrm{T} 3$, may be a positive regulator of the complement system via kallikrein-kinin system activation. By contrast, ceruloplasmin, a downregulated protein at T3, may be a major negative regulator of the complement system via its antioxidant capacity. Thus, both the increased complement activator and several decreased complement regulators could result in the rapid rise of the SC5b-9 level at $\mathrm{T} 3$ in the DHCA + SCP patients. During normothermic CPB, the levels of C5a and SC5b-9 did not change significantly from $\mathrm{T} 2$ to $\mathrm{T} 3$ after an initial rise at T2, a finding consistent with the relatively unchanged iTRAQ ratio and with reports from previous studies $(14,16)$.

Although we used state-of-the-art iTRAQ labeling technology mass spectroscopy, a considerable number of proteins expressed at low levels may not have been detected because of the large dynamic range in plasma proteins (24). Nevertheless, this technology may become a useful analytical tool in the field of research of biocompatibility of CPB in the future. The comparisons here involved two groups in which the two sets of patients underwent similar thoracic aortic surgery, i.e., DHCA + SCP and normothermic CPB. However, significant differences between the two groups occurred in the CPB time, which in turn affected T3 sampling time, implementation of circulatory arrest and SCP (hypothermic ischemia of lower body), and levels of $\mathrm{PaCO}_{2}$ and $\mathrm{Hb}$ at $\mathrm{T} 2$. These differences may affect plasma proteomic profiles. To elucidate the effects of hypothermia (and rewarming) per se on the biocompatibility of CPB, it may be necessary to perform a study using an animal model in the future.

In conclusion, results of the comparative iTRAQ proteomic analysis demonstrated that CPB-induced complement activation (and proteolysis) was initially suppressed during DHCA and later upregulated at the end of CPB after rewarming. Single and multiple regression analyses showed that this complement activation/suppression was associated with changes in expression of ceruloplasmin and six other proteins including CA1.

\section{Acknowledgements}

We thank Yasuko Sonoyama for the sample collection and technical assistance. This study was supported by a Grant-in Aid for Scientific Research (B) from the Japan Society for the Promotion of Science (nos. 21390389 and 23659845).

\section{References}

1. Luehr M, Bachet J, Mohr FW and Etz CD: Modern temperature management in aortic surgery: the dilemma of moderate hypothermia. Eur J Cardiothorac Surg 45: 27-39, 2014.

2. Griepp RB and Di Luozzo G: Hypothermia for aortic surgery. J Thorac Cardiovasc Surg 145 (Suppl 3): S56-S58, 2013.

3. Goldstein DJ, DeRosa CM, Mongero LB Weinberg AD, Michler RE, Rose EA, Oz MC and Smith CR: Safety and efficacy of aprotinin under conditions of deep hypothermia and circulatory arrest. J Thorac Cardiovasc Surg 110: 1615-1621, 1995.

4. Minatoya K, Ogino H, Matsuda H, Sasaki H, Tanaka H, Kobayashi J, Yagihara T and Kitamura S: Evolving selective cerebral perfusion for aortic arch replacement: high flow rate with moderate hypothermic circulatory arrest. Ann Thorac Surg 86: 1827-1831, 2008.

5. Wu L, Candille SI, Choi Y, Xie D, Jiang L, Li-Pook-Than J, Tang $\mathrm{H}$ and Snyder M: Variation and genetic control of protein abundance in humans. Nature 499: 79-82, 2013.

6. Pottiez G, Wiederin J, Fox HS and Ciborowski P: Comparison of 4-plex to 8-plex iTRAQ quantitative measurements of proteins in human plasma samples. J Proteome Res 11: 774-3781, 2012.

7. Satoh K, Maniwa T, Oda T and Matsumoto K: Proteomic profiling for the identification of serum diagnostic biomarkers for abdominal and thoracic aortic aneurysms. Proteome Sci 11: 27, 2013.

8. Lancaster TS, Jefferson SJ, Hunter JC, Lopez V, Van Eyk JE, Lakatta EG and Korzick DH: Quantitative proteomic analysis reveals novel mitochondrial targets of estrogen deficiency in the aged female rat heart. Physiol Genomics 44: 957-969, 2012.

9. Mi H, Muruganujan A, Casagrande JT and Thomas PD: Large-scale gene function analysis with the PANTHER classification system. Nat Protoc 8: 1551-1566, 2013.

10. Ashburner M, Ball CA, Blake JA, et al: Gene ontology: tool for the unification of biology. Nat Genet 25: 25-29, 2000.

11. Kelly RF, Cabrera JA, Ziemba EA, Crampton M, Anderson LB, McFalls EO and Ward HB: Continued depression of maximal oxygen consumption and mitochondrial proteomic expression despite successful coronary artery bypass grafting in a swine model of hibernation. J Thorac Cardiovasc Surg 141: 261-268, 2011.

12. Kourliouros A, Yin X, Didangelos A, Hosseini MT, Valencia O, Mayr M and Jahangiri M: Substrate modifications precede the development of atrial fibrillation after cardiac surgery: a proteomic study. Ann Thorac Surg 92: 104-110, 2011.

13. Lynn DJ, Chan C, Naseer M, Yau M, Lo R, Sribnaia A, Ring G, Que J, Wee K, Winsor GL, Laird MR, Breuer K, Foroushani AK, Brinkman FS and Hancock RE: Curating the innate immunity interactome. BMC Syst Biol 4: 117, 2010.

14. Salama A, Hugo F, Heinrich D, Höge R, Müller R, Kiefel V, Mueller-Eckhardt $\mathrm{C}$ and Bhakdi S: Deposition of terminal C5b-9 complement complexes on erythrocytes and leukocytes during cardiopulmonary bypass. N Engl J Med 318: 408-414, 1988.

15. Kouchoukos NT, Blackstone EH, Doty DB, Hanley FL and Karp RB (eds.): Hypothermia, circulatory arrest, and cardiopulmonary bypass. In: Kirklin/Barratt-Boyes, Cardiac Surgery: Morphology, Diagnostic Criteria, Natural History, Techniques, Results, and Indications. 3rd edition. Churchill Livingstone, Philadelphia, PA, pp91-96, 2003. 
16. Marcheix B, Carrier M, Martel C, Cossette M, Pellerin M Bouchard D and Perrault LP: Effect of pericardial blood processing on postoperative inflammation and the complement pathways. Ann Thorac Surg 85: 530-535, 2008.

17. Videm V, Mollnes TE, Garred P and Svennevig JL: Biocompatibility of extracorporeal circulation. In vitro comparison of heparin-coated and uncoated oxygenator circuits. J Thorac Cardiovasc Surg 101: 654-660, 1991.

18. Mahmood S, Bilal H, Zaman $\mathrm{M}$ and Tang A: Is a fully heparin-bonded cardiopulmonary bypass circuit superior to a standard cardiopulmonary bypass circuit? Interact Cardiovasc Thorac Surg 14: 406-414, 2012.

19. Thiara AS, Mollnes TE, Videm V, Anderson VY, Svennevig K, Kolset SO and Fiane AE: Biocompatibility and pathways of initial complement pathway activation with Phisio- and PMEA-coated cardiopulmonary bypass circuits during open heart surgery. Perfusion 26: 107-114, 2011.

20. Gabriel EA, Montevilla FM, Chida VV, Dias FN, Montoya CV Otsubo H, Pires ZF and Nogaroto SL: Experimental research with synthetic copolymer-coated cardiopulmonary bypass circuits: inflammatory and thrombogenicity analysis. Artif Organs 36: 110-114, 2012.

21. Smith PK, Shernan SK, Chen JC, Carrier M, Verrier ED, Adams PX, Todaro TG, Muhbaier LH, Levy JH and PRIMO-CABG II Investigators: Effects of C5 complement inhibitor pexelizumab on outcome in high-risk coronary artery bypass grafting: combined results from the PRIMO-CABG I and II trials. J Thorac Cardiovasc Surg 142: 89-98, 2011.

22. Baig K, Nassar R, Craig DM, Quick G Jr, Jiang HX, Frank MM Lodge AJ, Anderson PA and Jaggers J: Complement factor 1 inhibitor improves cardiopulmonary function in neonatal cardiopulmonary bypass. Ann Thorac Surg 83: 1477-1483, 2007.

23. Umstead TM, Lu CJ, Freeman WM, et al: The kinetics of cardiopulmonary bypass: a dual-platform proteomics study of plasma biomarkers in pediatric patients undergoing cardiopulmonary bypass. Artif Organs 36: E1-E20, 2012.

24. Anderson NL, Polanski M, Pieper R, Gatlin T, Tirumalai RS Conrads TP, Veenstra TD, Adkins JN, Pounds JG, Fagan R and Lobley A: The human plasma proteome: a nonredundant list developed by combination of four separate sources. Mol Cell Proteomics 3: 311-326, 2004.

25. Chello M, Mastroroberto P, Romano R, Ascione R, Pantaleo D and De Amicis V: Complement and neutrophil activation during cardiopulmonary bypass: a randomized comparison of hypothermic and normothermic circulation. Euro J Cardiothorac Surg 11: 162-168, 1997.
26. Polderman KH: Mechanisms of action, physiological effects, and complications of hypothermia. Crit Care Med 37 (Suppl 7): 186-202, 2009

27. Bisschops LL, Hoedemaekers CW, Mollnes TE and van der Hoeven JG: Rewarming after hypothermia after cardiac arrest shifts the inflammatory balance. Crit Care Med 40: 1136-1142, 2012

28. Oda T, Shimizu K, Yamaguchi A, Satoh K and Matsumoto K: Hypothermia produces rat liver proteomic changes as in hibernating mammals but decreases endoplasmic reticulum chaperones. Cryobiology 65: 104-112, 2012.

29. Ehrnthaller C, Ignatius A, Gebhard F and Hurber-Lang M: New insights of an old defense system: structure, function, and clinical relevance of the complement system. Mol Med 17: 317-329, 2011.

30. Rauen U, Petrat F, Li T and de Groot H: Hypothermia injury/cold-induced apoptosis-evidence of an increase in chelatable iron causing oxidative injury in spite of low $\mathrm{O}_{2}^{-} / \mathrm{H}_{2} \mathrm{O}_{2}$ formation. FASEB J 14: 1953-1964, 2000.

31. Gao BB, Clermont A, Rook S, Fonda SJ, Srinivasan VJ, Wojtkowski M, Fujimoto JG, Avery RL, Arigg PG, Bursell SE, Aiello LP and Feener EP: Extracellular carbonic anhydrase mediates hemorrhagic retinal and cerebral vascular permeability through prekallikrein activation. Nat Med 13: 181-188, 2007.

32. Kramer MD, Schaefer BM and Reinartz J: Network interactions of the complement system with other serum mediator systems. In: The Complement System. Rother K, Till GO, Hansch GM, (eds.). 2nd revised edition. Springer-Verlag, Berlin Heidelberg, pp324-341, 1998.

33. Kaplan AP and Ghebrehiwet B: The plasma bradykinin-forming pathways and its interrelationships with complement. Mol Immunol 47: 2161-2169, 2010.

34. Tapryal N, Mukhopadhyay C, Das D, Fox PL and Mukhopadhyay CK: Reactive oxygen species regulate ceruloplasmin by a novel mRNA decay mechanism involving its 3'-untranslated region: implications in neurodegenerative diseases. J Biol Chem 284: 1873-1883, 2009.

35. Chapman AL, Mocatta TJ, Shiva S, Seidel A, Chen B, Khalilova I, Paumann-Page ME, Jameson GN, Winterbourn CC and Kettle AJ: Ceruloplasmin is an endogenous inhibitor of myeloperoxidase. J Biol Chem 288: 6465-6477, 2013. 